\title{
Gender analysis of agricultural financing in cocoa-based farming system in Oyo and Osun States of South Western Nigeria
}

\author{
T.B. ALAO, A.S. BAMIRE \& A.D. KEHINDE* \\ (T.BA, A.S.B \& A.D.K.: Department of Agricultural Economics, Faculty of Agriculture, \\ Obafemi Awolowo University, Ile Ife, Osun State, Nigeria) \\ *Corresponding author's email: kehindeayodeji8@gmail.com
}

\begin{abstract}
This paper aimed to study the gender differentials in agricultural financing in cocoa-based farming systems in Southwestern Nigeria. A multi stage sampling procedure was employed to select 200 cocoa farmers for the study. Data were analyzed using descriptive statistics and logit regression model. The results revealed that cooperative societies are dominant sources of finance for both male and female cocoa farmers. The findings also revealed that male cocoa farmers have more sources of finance than their female counterparts in the study area. The determinant of access to finance for both male and female cocoa farmers was age; specific to male cocoa farmers were average income, household size and membership in cooperative societies while level of education and possession of collateral were specific to female cocoa famers. It was concluded that policy strategies aimed at improving access to finance must consider education and ownership of certain resources among female cocoa farmers and formation of cooperative societies among male cocoa farmers.
\end{abstract}

Keywords: Gender; Agricultural financing; Cocoa; Farming system; Humidtropics; Oyo Osun State.

Original scientific paper. Received 29 Jul 2019; revised 17 Feb 2020

\section{Introduction}

Cocoa-based farming system is the practice in which cocoa trees meant for the production of cocoa beans are the dominant component of the agro-forestry and usually inter-planted with other food crops e.g. cassava, maize and fruits. In Nigeria, cocoa (Theobroma Cacao) is a welladapted agro-forestry plantation crop grown in hot, rainy climates of Southwestern Nigeria inclusive of Ekiti, Ogun, Ondo, Osun, and Oyo (Cadoni, 2013; Oluwasola et al., 2015; Olaiya, 2016). Cocoa has played significant role in
Nigeria economy, especially in providing jobs and income to farmers, raw materials for the industry and foreign exchange for the country (Alamu, 2013). The contribution of cocoa to these producing States is appreciably substantial, hereby boosting the economies of these States (Eze, 2018).

Despite its contribution, cocoa growth witnessed a downward trend after the 1971 cropping season, and kept on declining till date (FAO, 2016). Several authors (Akinagbe, 2015; Olaiya, 2016; Afolayan, 2017) have

Ghana Jnl Agric. Sci. 55 (1), 34 - 42

GJAS is an Open Access Journal and distributed under the terms of the Creative Commons (CC) License [CC BY 4.0] 
ascribed this downward trend of cocoa production to myriad of problems such as the dominance of smallholders in the cocoa production sector such as low yield, ageing of cocoa trees, old age of farmers, constant use of farmlands, less emphasis on cocoa production, inadequate cocoa input subsidy programmes, poor financing and small cocoa farms.

Among these factors, poor financing is viewed as the most important and the most talked about problem of cocoa production (Mathew \& Uchechukwu, 2014; Mgbakor et al., 2014). Poor agricultural financing refers to low financial capability of farmers and limited access to external fund which results to low financial resource for agricultural production. Poor agricultural financing is a major impediment to cocoa production in recent times which arises from problems of the risky nature of cocoa production and lack of collateral to secure external fund (Adekoya, 2014; Ijioma \& Osondu, 2015 and Ajayi \& Obademi, 2018). The poor cocoa financing has been attributed to a number of socio-economic and institutional factors inclusive of gender stratification in access to finance (Akpan et al., 2013; Sheahan \& Barret, 2014; Perez et al., 2015).

Though several studies (Adebayo \& Adeola, 2008; Ammani, 2012 and Ololade \& Olagunju, 2013) have been conducted on access to finance among farmers in Nigeria, majority of the studies are not gender sensitive. Gender inequality is a problem which has characterized the agricultural financing (Jost et al., 2015; Huyer et al., 2015). Both men and women contribute significantly to agricultural production yet, their access to agricultural resources like credit differs (United Nations, 2015). Women are more constrained than their men counterparts in terms of access to credits (Tall et al., 2014, Twyman et al., 2014; UN Women et al., 2015).This could be linked to varying factors such as their low socioeconomic status, therefore rendering them unable to make important decisions over use of productive resources leading to little or no benefits accruing from farm production. Considering the cultural setting and the nature of environment where agricultural activities are practiced in some communities in Nigeria, women find it more difficult than men to gain access to valuable resources such as credit that would enhance their production capacity.

In view of this, the 'Humidtropics' (a CGIAR Research Program) that is led by International Institute of Tropical Agriculture (IITA) aimed at development of transformative innovation strategies for gender equity by improving the targeting and design of innovations to take account of salient gender norms in accessing finance by cocoa farmers is being implemented. Gender is core in systems research and a central theme in Humidtropics program, focusing on the reduction in gender disparities in access to inputs, services and technologies, a reduction in the drudgery of women's labour and an increase in productivity in men and women-managed farms. In order to achieve this, understanding the gender variations in the agricultural financing becomes imperative. Thus, this paper aimed to study the gender differentials in agricultural financing in cocoa-based farming systems in Southwestern Nigeria. Specifically, profile the sources of finance available to male and female cocoa farmers and determine factors that affect access to finance by male and female cocoa farmers.

\section{Area of study}

\section{Materials and Methods}

The study area was Southwestern Nigeria with a geographical area covering between latitude $60^{\circ}$ North and $40^{\circ}$ South and longitude $40^{\circ}$ West and $60^{\circ}$ East. It covers a land area of 
approximately $114,271 \mathrm{~km}^{2}$ which represents about $12 \%$ of the total land area in the country. It comprises six States which include: Lagos, Ogun, Oyo, Osun, Ondo and Ekiti states. The climate of Southwestern Nigeria is tropical in nature and it is characterized by wet and dry seasons. The temperature ranges between $21^{\circ} \mathrm{C}$ and $34^{\circ} \mathrm{C}$ while the annual rainfall ranges between $1500 \mathrm{~mm}$ and $3000 \mathrm{~mm}$. The vegetation in Southwestern Nigeria is rain forest in the south and guinea savannah in upper north. The climate in the region favours the cultivation of crops like maize, yam, cassava, millet, rice and plantain. The dominant tree crops are cocoa, palm tree, Kola nut, coffee and cashew. Commercial banks, merchants, Agricultural banks, microfinance banks, cooperative societies are commonly used financial institutions by the farmers in this area. This study was carried out on Innovation platform site of Humidtropics project. The Humidtropics research project has four field sites located in Oyo and Osun States. These field sites host innovation platforms in special local governments areas in each State.

\section{Sampling Procedure and Sample Size}

A multi-stage sampling procedure was used to select respondents for the study. The first stage was a simple random selection of cocoa producing states in South-western Nigeria (Oyo and Osun States). The second stage was a purposive sampling of four field sites namely Akindele, Lagbedu and Iwara, Osunwoyin in Oyo and Osun States respectively due to the on-going humid tropics project in these States and historical cocoa production significance. At the third stage, 50 cocoa farmers registered with the State Agricultural Development Programme (ADP) who were also members of the Innovation Platform (IP) in the on-going humid tropics programme were randomly selected from each of the four field sites using simple random technique, making a total of 200 cocoa farmers comprising of 148 male farmers and 52 female farmers.

\section{Analytical Technique}

Data were analysed using descriptive statistics and Logit regression model. Descriptive statistics such as frequency distribution and percentages were used to describe the sources of finance available to cocoa farmers

\section{Logit regression model}

Logit regression model was used to determine the factors that affect access to finance by male and female cocoa farmers in the study area. The choice of the logit model was based on the fact that the dependent variable is dichotomous. Following Gujarati (1998), the model was employed to estimate the factors that affect access to finance by male and female cocoa farmers in the study area.

The model is implicitly specified as follows:

$\operatorname{Ln} Y=\operatorname{Ln}\left(P i / 1-P_{i}\right)=\beta_{0}+\beta_{1} X_{1}+\beta_{2} X_{2}+\cdots+\beta_{8} X_{8}+\mu_{i}$

Where $\mathrm{Y}=$ is a binary variable defined as 1 for access to credit and 0 for otherwise.

$\mathrm{P}_{\mathrm{i}}=$ Probability to access credit

$1-\mathrm{P}_{\mathrm{i}}=$ Probability of no access to credit

$\mathrm{Ln}=$ Natural logarithm function

$\beta_{0}=$ Constant

$\beta_{1}-\beta_{n}=$ Logistic regression coefficients

$X_{1}-X_{n}=$ explanatory variables defined below as

$\mathrm{X}_{1}=$ Age of respondent (Years)

$\mathrm{X}_{2}=$ Formal educational level of respondent

(Year)

$\mathrm{X}_{3}=$ Respondent's farm size (Hectares) 
$\mathrm{X}_{4}=$ Respondent's farm income (

$\mathrm{X}_{5}=$ Household size (Actual)

$\mathrm{X}_{6}=$ Interest rate $(\%)$

$\mathrm{X}_{7}=$ Membership of organization (1 if yes, 0

if otherwise)

$\mathrm{X}_{8}=$ Possession of collateral ( 1 if yes, 0 if otherwise)

$\mu=$ Error term

The inclusion of these variables in the model was based on a prior expectation on the variable used. These explanatory variables are expected to influence the access to finance.

\section{Results and Discussions}

Source of finance available to cocoa farmers by gender

The source of agricultural financing, either in cash or kind, available to cocoa farmers in the study area ranged from family and friends, cooperative thrift associations or cooperative societies, produce buyers or merchants, to commercial banks, microfinance banks, agricultural banks, merchants (Table 1).

TABLE 1

Source of Finance Available to Cocoa Farmers by Gender

\begin{tabular}{llll}
\hline Source of finance & $\begin{array}{l}\text { Pooled } \\
(\mathbf{n = 2 0 0 )} \\
\text { Frequency (\%) }\end{array}$ & $\begin{array}{l}\text { Male } \\
(\mathbf{n = 1 4 8 )} \\
\text { Frequency (\%) }\end{array}$ & $\begin{array}{l}\text { Female } \\
(\boldsymbol{n}=\mathbf{5 2}) \\
\text { Frequency (\%) }\end{array}$ \\
Cooperative societies & $85(42.5)$ & $58(29)$ & $27(13.5)$ \\
Commercial banks & $14(7)$ & $10(5)$ & $4(2)$ \\
Microfinance banks & $10(5)$ & $6(3)$ & $4(2)$ \\
Agricultural banks & $13(6.5)$ & $9(4.5)$ & $4(2)$ \\
Merchant & $61(30.5)$ & $52(26)$ & $9(4.5)$ \\
Friends and family & $17(8.5)$ & $13(6.5)$ & $4(2)$ \\
\hline
\end{tabular}

Source: Field survey, 2017

According to Table 1, larger proportion of male cocoa farmers $(29 \%)$ sourced for finance from cooperative societies than their female counterparts (13.5\%). This is in line with Jeiyol et al. (2013) that male cocoa farmers had access to finance from cooperative societies than their female counterparts. Similarly, majority of male cocoa farmers (5\%) sourced for finance from commercial banks than their female counterpart (2\%). Larger proportion of male cocoa farmers $(26 \%)$ than their female counterpart $(4.5 \%)$ sourced for finance from merchants (produce buyers). They sourced for finance from merchant when they are out of season to produce cocoa and pay the merchants back with cocoa produce equivalent to that amount borrowed at harvest. Furthermore, more male cocoa farmers $(6.5 \%)$ than female cocoa farmers $(2 \%)$ accessed finance from other sources like friends and family members. The study revealed that cooperative societies is the major source of finance for both male and female cocoa farmers. This finding is in line with Agbo et al. (2015) who found that a larger percentage of farmers accessed finance from the cooperative society they belong. The study also revealed that male cocoa farmers have more sources of credit than their female counterparts in the study area. This could be attributed to socio cultural believes and norms 
as well as lack of collateral on the part of female farmers (Bamire et al., 2012).

Factors Affecting Access to Finance by Gender The factors that affect the access to credit by male and female cocoa farmers are shown in
Table 2. The significance of the diagnostic statistics (chi-squared and log-likelihood values) showed a good fit of the model.

TABLE 2

Factors affecting access to finance by male and female cocoa farmers

\begin{tabular}{|c|c|c|c|c|}
\hline \multirow{2}{*}{ Variable } & \multicolumn{2}{|c|}{ Marginal } & \multicolumn{2}{|c|}{ Female Marginal } \\
\hline & Coefficients & Effects & Coefficients & Effects \\
\hline \multirow{2}{*}{ Age } & $-0.0002 *$ & $-0.0005^{*}$ & $-1.663 * *$ & $-0.413^{* *}$ \\
\hline & $(0.100)$ & $(0.100)$ & $(0.051)$ & $(0.051)$ \\
\hline \multirow{2}{*}{ Education } & 0.075 & 0.019 & $0.011^{*}$ & $0.002 *$ \\
\hline & $(0.658)$ & $(0.658)$ & $(0.104)$ & $(0.101)$ \\
\hline \multirow{2}{*}{ Average income } & $-0.002 *$ & $0.0004 *$ & -0.002 & -0.001 \\
\hline & $(0.105)$ & $(0.105)$ & $(0.390)$ & $(0.390)$ \\
\hline \multirow{2}{*}{ Marital status } & -0.038 & 0.009 & -0.035 & -0.008 \\
\hline & $(0.501)$ & $(0.501)$ & $(0.689)$ & $(0.689)$ \\
\hline \multirow{2}{*}{ Farm size } & -0.172 & 0.043 & 0.458 & 0.113 \\
\hline & $(0.358)$ & $(0.358)$ & $(0.412)$ & $(0.411)$ \\
\hline \multirow{2}{*}{ Farm experience } & 0.213 & 0.053 & 0.584 & 0.145 \\
\hline & $(0.304)$ & $(0.304)$ & $(0.160)$ & $(0.160)$ \\
\hline \multirow{2}{*}{ Household size } & $0.549 *$ & $0.137 *$ & 0.044 & 0.011 \\
\hline & $(0.060)$ & $(0.060)$ & $(0.939)$ & $(0.939)$ \\
\hline \multirow{2}{*}{ Interest rate } & 0.096 & 0.024 & 0.058 & 0.014 \\
\hline & $(0.461)$ & $(0.461)$ & $(0.824)$ & $(0.824)$ \\
\hline \multirow{2}{*}{ Possession of collateral } & -0.736 & -0.178 & 1.934 & $0.372 * *$ \\
\hline & $(0.145)$ & $(0.125)$ & $(0.231)$ & $(0.056)$ \\
\hline \multirow{2}{*}{ Membership of organization } & $1.132 * * *$ & $0.271 * * *$ & -0.300 & 0.074 \\
\hline & $(0.005)$ & $(0.002)$ & $(0.744)$ & $(0.741)$ \\
\hline \multirow[t]{2}{*}{ Constant } & 1.839 & 7.841 & & \\
\hline & $(0.307)$ & $(0.151)$ & & \\
\hline Number of observations & 148 & 52 & & \\
\hline Likelihood Ratio $\operatorname{chi}^{2}(10)=$ & 18.20 & 16.63 & & \\
\hline Prob $>\mathrm{chi}^{2}=$ & 0.0517 & 0.0030 & & \\
\hline Log likelihood $=$ & -129.4888 & -113.565 & & \\
\hline
\end{tabular}

NB; * Significant at 10\%; ** Significant at 5\%;*** Significant at 1\%. Figures in parentheses are the p-value

Source: Field survey, 2017

From Table 2, age significantly influenced access to finance for the entire sample. The age of male and female cocoa farmers negatively and significantly influenced the likelihood of access to finance. This implies that a year increase in the age of male and female cocoa farmers would reduce the probability of access to finance by $0.05 \%$ and $41.3 \%$, respectively. This implies that older cocoa farmers demand for lesser amount of credit compared to young ones in the study area. This confirms the findings of Ayodele et al. (2016) 
A gender analysis of the factors driving the access to finance showed some variations. For male farmers, average income, household size and membership of farmers' organization significantly influenced access to finance. The average annual income of cocoa farmers negatively and significantly influenced the probability of access to finance by male cocoa farmers. This implies that an increase in income of cocoa farmers decreases the likelihood of access to finance from financial institutions by $0.04 \%$. This is in line with the findings of Ijioma and Osondu (2015) that increase in income will reduce the need for external financing of farm activities. Household size positively and significantly influenced the probability of accessing finance. This suggests that an increase in household size of male cocoa farmers increases the likelihood of accessing finance by $13.7 \%$. This suggests that the higher the number of household member the higher the demand for credit from external sources. This is in line with Oboh and Ekpebu (2011) who reported that household size increases the likelihood of accessing finance Membership of organizations positively and significantly influences the likelihood of accessing finance from financial institutions. This suggests that an increase in membership of farmers' organization increases access to finance by $0.2 \%$. This implies that being a member of organization increases farmers chances of getting credit all things being equal. This is in line with Isitor et al. (2014) who reported that belonging to membership of organizations increases the likelihood of accessing finance.

On the other hand, education and possession of collateral significantly influenced access to finance by female cocoa farmers. Education of female cocoa farmers positively and significantly $(\mathrm{p}<0.1)$ influenced their likelihood of accessing finance. This implies that a unit increase in the years of education of female cocoa farmers increases the likelihood of access to finance by $0.2 \%$. This is because at certain educational levels, a farmer is able to make informed decisions concerning the demand for credit. This finding tally with Ibrahim et al. (2012). The possession of collateral positively and significantly $(p<0.1)$ influenced their likelihood of accessing finance of female cocoa farmers. The result suggests that an increase in possession of collaterals by female cocoa farmers increases the probability of accessing finance by $37.2 \%$. This finding tally with Adekoya (2014).

\section{Conclusion and Recommendation}

Cocoa is one of the major crops vastly produced in the study area with main gender variations in the source of agricultural financing and factors affecting access to credit in the study area. However, male cocoa farmers had more access to finance than their female counterpart which may be attributed to lack of collateral on the part of female farmers. However, while age was the major factor that affects access to finance by male and female cocoa farmers, average income, level of education, and household size were major factors that affect access to finance by male cocoa farmers. Level of education and possession of collateral were the major factors for female cocoa farmers in the study area. This suggests that while strategies targeted at promoting the access to finance among male farmers should consider average income, level of education, and household size, strategies among female should consider level of education and possession of collateral. Following the findings of the study, it is recommended that youth should be encouraged to go into cocoa production as 
age of farmers affect their access to finance as financial institutions pays more attention to younger farmers than the older farmers and Government should ensure promotion of education and ownership of certain resource among female cocoa farmers. Also, gender sensitive agricultural support systems and policies which will favour female farmers in accessing, use and control of agricultural resources so as to increase their outputs should be put in place. Finally, the socio-economic factors should be considered when providing financial services to male and female farmers and the formal institutions should simplify the procedures required for providing financial services to the male and female farmers.

\section{REFERENCES}

Adebayo, O. O. \& Adeola, R.G. (2008) Sources and uses of agricultural credit by small scale farmers in Surulere Local Government Area of Oyo State. Anthropologist 10 (4), 313 -314.

Adekoya, O. A. (2014) The Patterns and Determinants of Agricultural Credit use Among Farm Households in Oyo State, Nigeria. Asian Economic and Financial Review 4 (10), 1290 $-1297$.

Afolayan S.O. (2017) Problems and Prospects of cocoa Production in Nigeria Economy: A Review. International Journal of Social Science 11(2), $32-43$.

Agbo, F. U., Iroh, I. I. \& Ihemezie, E. J. (2015). Access to credit by vegetable farmers in Nigeria: A case study of Owerri Agricultural Zone of Imo State, Nigeria. Asian Journal of Agricultural Research 9 (4), 155 - 165.

Ajayi, S. \& Obademi, O. (2018) The determinants and impact of access to agricultural credit on productivity by farmers in Nigeria; Evidence from Oyo State, Nigeria. Advances in Social Sciences Research Journal 5 (3), 252 - 265.
Akpan, S. B., Inimfon, V. P., Samuel, J. U., Edem, A. O. \& Uwemedimo, E. O. (2013) Determinants of Credit Access and Demand among Poultry Farmers in Akwalbom State, $\mathrm{N}$ i g e r i a . American Journal of Experimental Agriculture 3 (2), $293-307$.

Akinnagbe, O. M. (2015) Evaluation of constraints to implementation and adoption of cocoa resuscitation programmes in Southwest Nigeria. Applied Tropical Agriculture, 20(1), $42-47$.

Ammani, A. A. (2012) An investigation into the relationship between agricultural production a n d formal credit supply in Nigeria. International Journal of Agriculture and Forestry 2 (1), 46 52.

Alamu, S. A. (2013) Analysis of Seedling Subsidy Policy and Cocoa Production in SouthWest Nigeria. Journal of Educational and Social Research 3 (4), pp. 59.

Ayodele, O. V., Fasina, O. O. \& Awoyemi, A. O. (2016) Gender Analysis of CocoaFarmers' access to Production Resources in Ekiti State, Nigeria. Applied Tropical Agriculture 21 (3), $131-137$.

Bamire, A.S., Abdoulaye, T. \& Sanogo, D. (2012) "Determinants of improved maize adoption in Nigeria: Are they the same for poor and wellendowed households?" Ife Journal of Agriculture 25, 83 - 100.

Cadoni, P. (2013) Analysis of incentives and disincentives for cocoa in Nigeria. Technical notes series, MAFAP, FAO, and Rome.

Eze, J. (2018) Improving cocoa production. This Day Newspaper, Retrieved from http://www. thisdaylive.com/index.php/2018/09/12/ improving-cocoa-production.

Huyer, S., Twyman, J., Koningstein, M., Ashby, J. \& Vermeulen, S. (2015) Supporting women farmers in a changing climate: Five policy 
lessons. Agriculture and Food Security Programme. Copenhagen, Denmark: CGIAR Climate Change.

Ibrahim, S. S. \& Aliero, H. M. (2012) An analysis of farmers access to formal credit in the rural areas of Nigeria. African journal of agricultural research 7 (47), $6249-6253$.

Ijioma, J. C. \& Osondu, C. K. (2015) Agricultural Credit Sources and Determinants of Credit Acquisition by Farmers in Idemili Local Government Area of Anambra State, Nigeria.

Isitor, U., Babalola D. A. \& Obaniyi, K. S. (2015) An Analysis of credit Utilization and FarmIncome of Arable Crop Farmers in Kwara State, Nigeria Global Journal of Science Frontier Research 14 (10).

Jeiyol, E. N., Akpan, S. B. \& Terver, N. T. (2013) Gender analysis of access to credit by rural small-scale farmers in Benue state, Nigeria. An International Journal of Social Science 2 (6), $70-8$.

Jost, C., Kyazze, F., Naab, J., Neelormi, S., Kinyangi, J., Zougmore, R., Aggarwal, P., Bhatta, G., Chaudhury, M.,Tapio-Bistrom, M., Nelson, S. \& Kristjanson, P. (2015) Understanding gender dimensions of agriculture and climate change in smallholder farming communities. Climate and Development 8 (2), 1 - 12.

Mathew, A. O. \& Uchechukwu, A. A. (2014) Rural farmers sources and use of credit in Nsukka local government area of Enugu State, Nigeria. Asian Journal of Agricultural Research 8(4), $195-203$.

Mgbakor, M. N., Uzendu, P. O. \& Ndubisi, D. O. (2014) Sources of Agricultural Credit to SmallScale Farmers in Ezeagu Local Government Area of Enugu State, Nigeria. IOSR Journal of Agriculture and Veterinary Science (IOSRJAVS) 7 (8), 1 - 8.
Oboh, V.U. \& Ekpebu, I.D. (2011) Determinants of formal agricultural credit allocation to the farm sector by arable crop farmers in Benue State, Nigeria. African Journal of Agricultural Research 6 (1), 181 - 185.

Olaiya, T.A. (2016) Examining the Political Economy of Cocoa Exports in Nigeria. International Journal of applied Economics and Finance 10, $1-13$.

Ololade, R.A. \& Olagunju, F.I. (2013) Determinants of access to credit among rural farmers in Oyo State, Nigeria. Global Journal of Science Frontier Research 13 (2).

Oluwasola, O., Ige, A. O. \& Omodara, D. (2015) Determinants of the responsiveness of Cooperative farmers to the renaissance programme in Osun state, Nigeria. Journal of development and Agricultural Economics 7 (4), 153 - 161.

Perez, C., Jones, E. M., Kristjanson, P., Cramer, L., Thornton, P. K., Forch, W. \& Barahona, C. (2015) How resilient are farming households and communities to a changing climate in Africa? A gender-based perspective. Global Environmental Change 34, $95-107$.

Sheahan, M., \& Barrett, C. B. (2014) Understanding the agricultural input landscape in Sub-

Saharan Africa: Recent plot, household, and community-level evidence (Policy Research Working Paper 7014). Washington, DC: World Bank.

Tall, A., Hansen, J., Jay, A., Campbell, B., Kinyangi, J., Aggarwal, P. K. \& Zougmoré, R. (2014) Scaling up climate services for farmers: Mission possible. Learning from good practice in Africa and South Asia (CCAFS Report No. 13). Copenhagen, Denmark: CGIAR Research Program on Climate Change, Agriculture and Food Security (CCAFS). 
Twyman, J., Green, M., Bernier, Q., Kristjanson, P., Russo, S., Tall, A., Ampaire, E., Nyasimi, M., Mango, J., McKune, S., Mwongera, C. \& Ndourba, Y. (2014) Adaptation actions in Africa: Evidence that gender matters (CCAFS 116 Gender, Technology and Development 20 (2) Working Paper 83). Copenhagen, Denmark: CGIAR Climate Change, Agriculture and Food Security Programme.
United Nations. (2015) The world's women 2015. New York: United Nations, Department of Economic and Social Affairs, Statistics Division.

UN Women, UNDP, UNEP, \& World Bank. (2015) The cost of the gender gap in agricultural productivity. New York: Author. 